\title{
A Study of Biodiesel Production from Non-Edible Oil Seeds: A Comparative Study
}

\author{
E.F Aransiola*, T.V Ojumu, O.O Oyekola, and D.I.O Ikhuomoregbe
}

Department of Chemical Engineering, Cape Peninsula University of Technology, Cape Town 8000, South Africa

\begin{abstract}
This study investigated production of biodiesel from non edible oil seeds of Jatropha curcas and neem. This is with a view to compare which of the oils when used for biodiesel production is more environmentally friendly and cheaper. The optimum reaction time for transesterification of Jatropha curcas oil to biodiesel was recorded to be 3h while that of neem oil to biodiesel was $2 \mathrm{~h}$. This reduces the operating cost of neem biodiesel. Fatty acid methyl esters (FAME) yield of $86.61 \%$ with a viscosity of 5.64 cSt was obtained for Jatropha biodiesel using the established operating conditions. This viscosity was used as an index for maximum conversion of biodiesel (BD) for neem oil. The viscosity obtained for neem oil biodiesel was 5.51cSt. An attempt to increase the reaction time does not give any significant difference in the viscosity. Experimental investigations of the different blends of biodiesel from the two oils were tested on an internal combustion engine. The emissions of different blends showed that neem biodiesel has lower emissions of $\mathrm{CO}$ and $\mathrm{NO}_{\mathrm{X}}$ than Jatropha biodiesel, but CO emissions of Jatropha biodiesel are lower than that of diesel fuel. The $\mathrm{NO}_{\mathrm{X}}$ value of petrol diesel is higher than B10 - B50 and B10 - B80 of Jatropha and Neem biodiesel respectively. However, $\mathrm{NO}_{\mathrm{X}}$ values of B60 - B100 and B90 - B100 of Jatropha and neem biodiesel are in the range of $5.27-10.74 \%$ and $1.39-11.93 \%$ higher than petrol diesel respectively. The physical properties of both biodiesel met the ASTM standard of D-6751.
\end{abstract}

Keywords: Biodiesel, Biofuel, Emissions, Jatropha curcas oil, Neem oil, Transesterification.

\section{INTRODUCTION}

The major percentages of energy used in the world today are being generated from fossil fuel sources. These fossil fuels are non-renewable resources that take millions of years to form and their reserves are being depleted faster than they are being regenerated. They are the major contributors and sources of green house gases, air pollution and global warming. Some of the emissions generated from these fossil fuels are $\mathrm{CO}, \mathrm{CO}_{2}, \mathrm{NO}_{\mathrm{x}}, \mathrm{SO}_{\mathrm{x}}$, unburnt or partially burnt $\mathrm{HC}$ and particulate. The production and use of these fossil fuels are raising environmental concerns [1]. This rate of depletion and environmental issue is seriously calling for an alternative. Biodiesel, a form of Biofuel is an answer to this call. It is a fuel derived from renewable biological sources to be used in a diesel engine. Biodiesel fuel is recently attracting increasing attention worldwide as a blending component or a direct replacement for diesel fuel in vehicle engines [2]. Biodiesel blends of up to B20 can be used in nearly all diesel equipment and are compatible with most storage and distribution equipment. These low-level blends generally do not require any engine modifications. Higher blends, even B100, can be used in many engines built with little or no modification [3]. Though biodiesel is gaining popularity, more than $95 \%$ of the renewable resources used for its production are edible oils [4] and these have been in conflict with food consumption and also more expensive than petroleum diesel.

*Address correspondence to this author at the Department of Chemical Engineering, Cape Peninsula University of Technology, Cape Town 8000, South Africa; Tel: +27 21460 3162; Fax: +27 21460 3854;

E-mail: aransiola4@yahoo.com
Due to this fact, it is necessary to look into non-edible oils which are not competitive with consumption and are also cheap. Globally, large amounts of non-edible oil plants are readily available in nature. The ideal vegetable oil for biodiesel must be readily available, its plant should be easy to cultivate and its composition must include a high percentage of mono-unsaturated fatty acids (C16:1, C18:1) [1]. Based on these criteria, Jatropha curcas and neem oils have been found to be useful renewable sources for biodiesel production.

Jatropha curcas is drought-resistant oil bearing multipurpose shrub/small tree, belonging to the family of Euphorbiaceae $[1,5]$. It originates from Central America and is widely grown in Mexico, China, north-east Thailand, India, Nepal, Brazil, Ghana, Mali, Foso, Zimbabwe, Nigeria, Malawi, Zambia and some other countries [5]. The plants grow quickly forming a thick bushy fence in a short period of time of 6-9 months, and growing to heights of $4 \mathrm{~m}$ with thick branches in 2-3 years [6]. It grows in arid and semi arid climates and in a wide range of rainfall regimes, from 200 to $1500 \mathrm{~mm}$ per annum [5]. It can survive in poor stony soils [7], and has a life span of 50 years [8]. Jatropha curcas can produce significant amounts of oil in their respective seeds ${ }^{1}$. The oil content of the seeds varies from 30 to $60 \%$ depending on the variety, place and the method of oil extraction [9].

Neem (Azadirochta indica A. Juss) is a native Indian tree well known for its medicinal features. Most of the parts such as leaves, bark, flower, fruit, seed and root have applications in the field of medicine [10]. It is an evergreen tree related to mahogany, growing in almost every state of India, South- 
East Asian countries and West Africa [11]. It grows in drier areas and in all kinds of soil. It contains several thousands of chemicals which are terpenoids in nature. A mature neem tree produces 30 to $50 \mathrm{~kg}$ fruit every year and has a productive life span of 150 to 200 years [11b]. It has the ability to survive on drought and poor soils at a very hot temperature of $44^{\circ} \mathrm{C}$ and a low temperature of up to $4^{\circ} \mathrm{C}$ [12], and its high oil content of 39.7 to $60 \%$ [13].

To date, reports on the use of these non edible oils, in particular neem oil from Nigeria, for the production of BD are not available while that of Jatropha curcas oil are limited [14]. The fatty acid compositions of the oils (Table 1) and their physico-chemical properties (Table 2) have been investigated previously [15]. This article presents the results of a study conducted on BD production from Nigerian non edible oils using alkali-catalyzed transesterification method, and tested in an internal combustion engine. This is with a view to compare which of the oils when used for biodiesel production is more environmentally friendly. The results of this study would form a basis for the development of a database for biodiesel production from these feedstocks, especially in countries where they are in abundance.

\section{MATERIALS AND METHODS}

\subsection{Materials}

The Jatropha curcas oil was obtained from Ikere-Ekiti while neem oil was bought from National Research Institute of Chemical Technology, Zaria in Nigeria. The conventional diesel fuel was purchased from Obafemi Awolowo University's filling station, Nigeria. Analytical grade chemicals including, methanol, sodium methoxide, anhydrous calcium chloride, sulphuric acid, sodium thiosulphate e.t.c. were obtained from Sigma Aldrich, Germany.

\subsection{Two-step Acid-base Catalyzed Transesterification}

These crude non edible oils when transesterified using $\mathrm{NaOH}$ catalyst produced a significant amount of soaps from saponification side reaction. Therefore, a two step process

Table 1. Fatty Acid Compositions of Jatropha Curcas Oil and Neem Oil

\begin{tabular}{|c|c|c|}
\hline Fatty Acid & Jatropha Curcas oil [22] & Neem oil [13] \\
\hline Myristic $14: 0$ & 0.1 & - \\
\hline Palmitic $16: 0$ & 14.2 & 18.1 \\
\hline Palmitoliec 16:1 & 0.7 & - \\
\hline Margaric 17:0 & 0.1 & - \\
\hline Stearic 18:0 & 7 & 18.1 \\
\hline Oleic 18:1 & 44.7 & 44.5 \\
\hline Linoleic $18: 2$ & 32.8 & 18.3 \\
\hline Linolenic 18:3 & 0.2 & 0.2 \\
\hline Arachidic 20:0 & 0.2 & 0.8 \\
\hline Saturated & 21.6 & 37 \\
\hline Monounsaturated & 45.4 & 44.5 \\
\hline Polyunsaturated & 33 & 18.5 \\
\hline
\end{tabular}

Table 2. The Physicochemical Properties of Neem oil and Jatropha Curcas Oil

\begin{tabular}{|c|c|c|}
\hline Properties & Neem Oil [15a] & Jatropha Oil [15b] \\
\hline \hline Acid Value (mgKOH/g) & 81.28 & 35.8 \\
\hline Iodine Value & @30 ${ }^{\circ} \mathrm{C} 43.75$ & 199.86 \\
\hline Viscosity (cSt) & Liquid(Golden yellow) & 193 \\
\hline Saponification & 13 & Liquid(Golden yellow) \\
\hline Physical state at room temperature & 7.0 & 10 \\
\hline Cloud point $\left({ }^{\circ} \mathrm{C}\right)$ & 918.2 & 2 \\
\hline Pour point $\left({ }^{\circ} \mathrm{C}\right)$ & 895 \\
\hline
\end{tabular}


acid catalyzed esterification followed by alkali catalyzed transesterification was employed according to the method of Berchmans and Hirata [16].

\subsubsection{Acid Pretreatment (Acid Catalyzed Esterification)}

The crude oil was heated at $60^{\circ} \mathrm{C}$ for about 10 mins and mixed with methanol $(60 \% \mathrm{w} / \mathrm{w}$ of oil). To the mixture was added $1-1.2 \% \mathrm{w} / \mathrm{w}$ of concentrated $\mathrm{H}_{2} \mathrm{SO}_{4}$. The resulting mixture was then stirred on a magnetic hot plate for $1 \mathrm{~h}$ at $50^{\circ} \mathrm{C}$, after which it was allowed to settle for $2 \mathrm{~h}$. The pretreated oil was separated from the methanol-water phase at the top.

\subsubsection{Base Catalyzed Transesterification}

Optimum reaction temperature and amount of catalyst concentration had been investigated and reported by [17] to be $333 \mathrm{~K}$ and $1 \mathrm{wt} \% \mathrm{NaOH}$ as reaction temperature and catalyst loading, respectively. The oil to alcohol ratio of 1:6 was also reported by [15b] to give the best result when compared with oil to alcohol ratios of 1:3 and 1:4. Batch reactions were carried out in a $250 \mathrm{~mL}$ Erlenmeyer flask containing $100 \mathrm{~g}$ of oil. These were done on a shaker at a temperature of $333 \mathrm{~K}$ keeping the rate of agitation constant at $200 \mathrm{rpm}$ for oil to alcohol ratio of 1:6. The alcohol used was methanol. A catalyst of $1 \%$ wt of sodium hydroxide was dissolved into an amount of alcohol according to the oil to alcohol ratio. The alcohol base mixture was added to the oil, and the reaction was allowed to run for various periods of $15 \mathrm{~min}, 30 \mathrm{~min}, 1$ h, 2 h, $3 \mathrm{~h}$ and $3.5 \mathrm{~h}$.

The sample collected was allowed to settle for twelve hours in a separating funnel by gravity settling into a clear, golden liquid biodiesel on the top with the light brown glycerol at the bottom. After this period, the glycerol was drained off from the bottom of the separating funnel. The raw biodiesel was water washed three times so as to remove the non - reacted catalyst and glycerol off. To get a pure biodiesel free of methanol, this was purified in a rotary evaporator in order to remove the excess methanol. Following this, the ester phase was dried over anhydrous calcium chloride. The biodiesel produced were analyzed for the following parameters: methyl esters, pour points, flash points, cloud points, density, moisture content and kinematic viscosity at $313 \mathrm{~K}$.

\subsection{Analysis}

\subsubsection{HPLC Method}

The HPLC analysis was conducted according to the method shown by Dubé et al. [18] and Darnoko and Cheryan [19].

\subsubsection{Characterization of $B D$}

The characterization of the biodiesel was carried out according to the methods used by Aransiola et al. [17]. The parameters are determined with the standard methods used which are presented in Table 3.

\subsection{Investigation of Biodiesel on Internal Combustion Engine}

The investigations on the combustion characteristics of the conventional diesel, neem methyl ester (B100) and its blends were conducted on a single cylinder one-stroke $165 \mathrm{~F}$ jet diesel engine having a rated output of $3.23 \mathrm{kw}$ at 2600 rpm. This was fueled with prepared test fuels. The emissions (CO and $\mathrm{NO}_{\mathrm{x}}$ ) were measured through an automatic EGA4 palm top flue gas analyzer having $\mathrm{Ni}-\mathrm{MH}$

\section{RESULTS AND DISCUSSION}

The production of biodiesel from Jatropha oil is depicted in Fig. (1). As can be observed from this figure, the FAME yields of $86.61 \%$ and $86.63 \%$ were obtained at reaction times of 3 and 3.5h respectively, with viscosity values found to be $5.64 \mathrm{cSt}$ and $5.65 \mathrm{cSt}$ respectively. Optimally, the reaction time of $3 \mathrm{~h}$ was chosen since there is no significant difference in both the FAME yield and the viscosity values of these reaction times. Similar observation has been reported by Bajpai and Tyagi [20]. In their study, Bajpai and Tyagi obtained maximum yield of FAME between $333 \mathrm{~K}$ and $353 \mathrm{~K}$ when oil to alcohol molar ratio was 1:6. The optimum viscosity result of the Jatropha curcas oil BD was used as a yardstick for BD from neem oil to determine when the conversion was complete. The viscosity values obtained for neem oil biodiesel at reaction times 2, 2.5 and 3h were approximately 5.51cSt (see Fig. 2). This implies that the conversion was complete at reaction time of $2 \mathrm{~h}$. The fuel properties of both Jatropha and neem biodiesel agree with the standards of the American Standard Testing Method. This is shown in Table 3.

The results for the various emission data generated are presented in Figs. (3 and 4). The emissions of different blends showed that neem biodiesel has lower emissions of $\mathrm{CO}$ and $\mathrm{NO}_{\mathrm{X}}$ than Jatropha biodiesel, but CO emissions of Jatropha biodiesel are lower than that of diesel fuel. The emissions of CO of both Jatropha and Neem biodiesel decreased as the biodiesel blends tend towards B100, and they both gave less carbon monoxide (CO) when compared to petrol diesel. The emissions of $\mathrm{NO}_{\mathrm{x}}$ increased with the biodiesel blends. The $\mathrm{NO}_{\mathrm{X}}$ value of petrol diesel is higher than B10 - B50 and B10 - B80 of Jatropha and Neem biodiesel

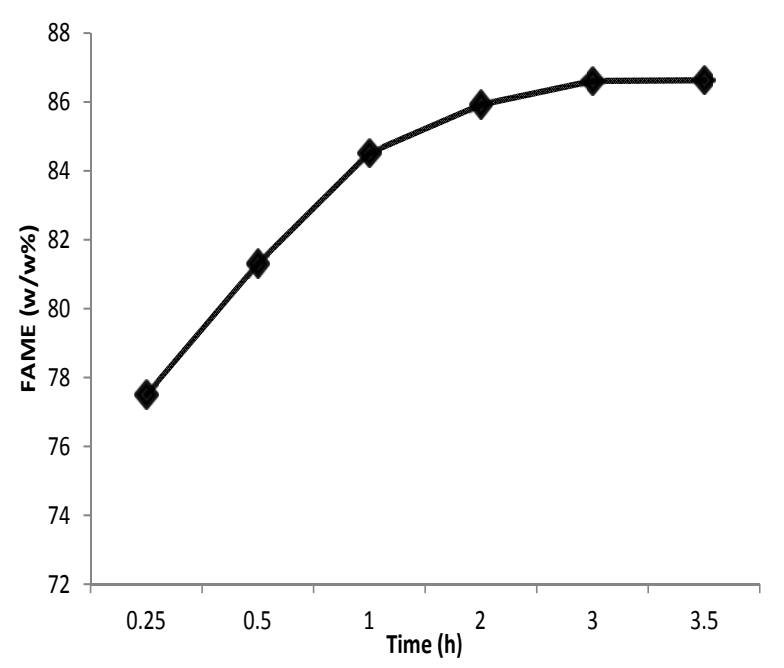

Fig. (1). Plot of fatty acid methyl ester concentration against Reaction Time at Reaction Temperature of 333K for oil to alcohol molar ratio 1:6. 


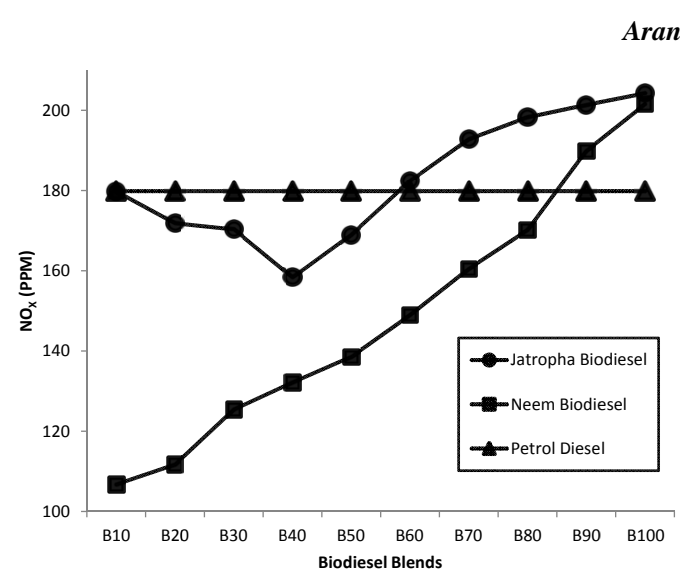

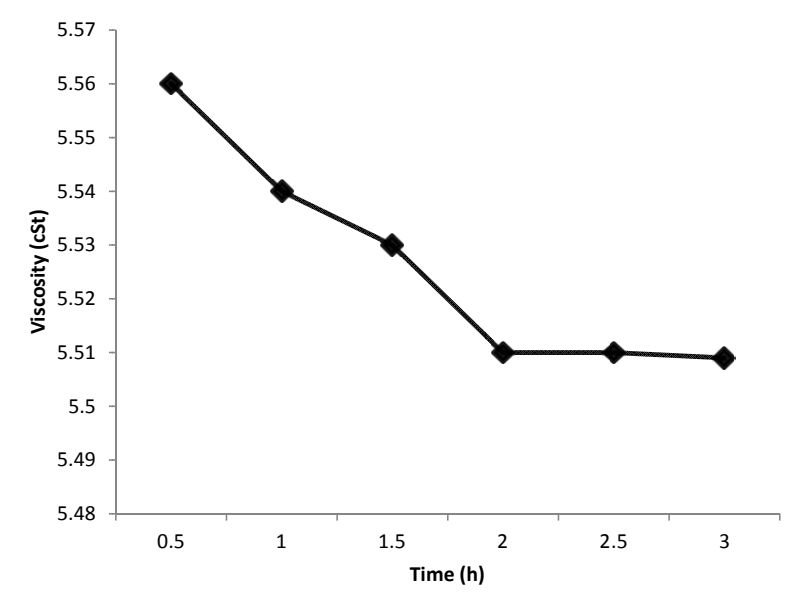

Fig. (2). Plot of Viscosity of Neem biodiesel against Reaction Time.

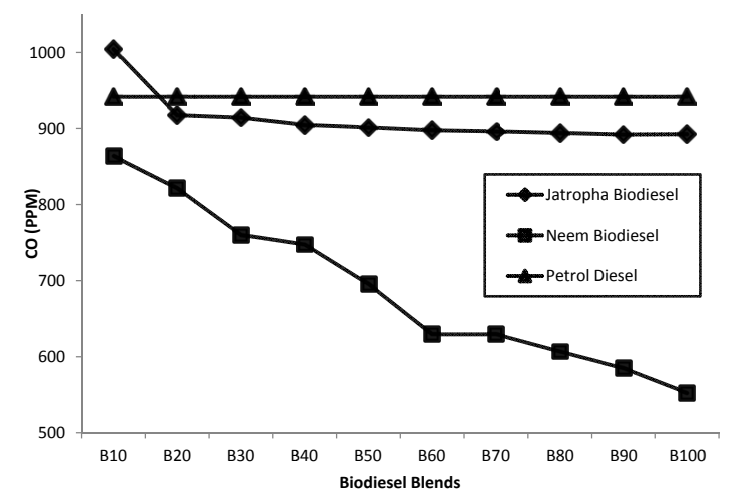

Fig. (3). The plot of CO Emissions against different Blends of Jatropha Biodiesel, Neem Biodiesel and Petrol Diesel.

respectively. However, $\mathrm{NO}_{\mathrm{X}}$ values of $\mathrm{B} 60$ - B100 and B90 - B100 of Jatropha and neem biodiesel are in the range of $5.27-10.74 \%$ and $1.39-11.93 \%$ higher than petrol diesel respectively. The percentage increment between B100 and diesel was $10.74 \%$. Previous investigation has shown similar trends for $\mathrm{CO}$, NO and NOx emissions while running the diesel engines with karanja, neem, Honge, Jatropha and sesame oil methyl esters [21].
Fig. (4). The plot of $\mathrm{NO}_{\mathrm{X}}$ Emissions against different Blends of Jatropha Biodiesel, Neem Biodiesel and Petrol Diesel.

Comparing the use of these two oils; Jatropha curcas oil and neem oil for biodiesel production with reference to emissions generated, biodiesel from neem oil was found more environmentally friendly and better. Considering the reaction time for complete conversion, neem biodiesel was found to have a reduced reaction time of $2 \mathrm{~h}$ compared to the $3 \mathrm{~h}$ completion time of Jatropha biodiesel; this reduced reaction time of neem biodiesel will lead to its reduced operating and production costs

\section{CONCLUSIONS}

In this article, a comparative study on the production of biodiesel from non edible oil seeds of Jatropha curcas and neem was carried out. The neem biodiesel and its blends were found to have lower emissions of $\mathrm{CO}$ and $\mathrm{NO}_{\mathrm{X}}$ than Jatropha biodiesel. This makes neem biodiesel to be more environmentally friendly than Jatropha biodiesel, though both of them were found to meet the American Standard Testing Method. The reaction time for complete conversion of neem oil to biodiesel is lower than that of Jatropha curcas oil to biodiesel; inferring lower production cost in neem biodiesel than in Jatropha biodiesel.

\section{ACKNOWLEDGEMENT}

The authors acknowledge the Education Trust Fund, Abuja in Nigeria and Cape Peninsula University of Technology for their financial supports, and also National Research

Table 3. Results of Characterization of Jatropha Curcas Oil Biodiesel and Neem Oil Biodiesel

\begin{tabular}{|c|c|c|c|c|}
\hline Properties & Jatropha curcas oil Biodiesel & Neem oil Biodiesel & Biodiesel Standard & Test Method \\
\hline \hline Flash point $\left({ }^{\circ} \mathrm{C}\right)$ & 170 & 149 & $130(\mathrm{~min})$ & ASTMD -93 \\
\hline Moisture content & $\mathrm{Nil}$ & $\mathrm{Nil}$ & $0.050 \mathrm{max}$ & ASTMD -2709 \\
\hline Kinematic viscosity & 5.64 & 5.51 & $1.9-6.0$ & ASTMD -445 \\
\hline Cloud Point $\left({ }^{\circ} \mathrm{C}\right)$ & 3 & 5 & $0.860-0.900$ & ASTMD - 2500 \\
\hline Specific gravity at $15 / 15^{\circ} \mathrm{C}$ & 0.880 & 0.876 & - & ASTMD - 97 \\
\hline Pour point $\left({ }^{\circ} \mathrm{C}\right)$ & -6 & 3 & $45-55$ & ASTM-D 975 \\
\hline Cetane Number & - & 46 & & - \\
\hline
\end{tabular}


Institute of Chemical Technology, Zaria for providing working space for carrying out analysis of the work. Aransiola wishes to thank NRF for supporting her research visit which culminates to the preparation of this manuscript.

\section{CONFLICT OF INTEREST}

None declared.

\section{REFERENCES}

[1] Wang, R.; Hanna, M. A.; Zhou, W.-W.; Bhadury, P. S.; Chen, Q.; Song, B.-A.; Yang, S. Production and selected fuel properties of biodiesel from promising non-edible oils: Euphorbia lathyris L., Sapium sebiferum L. and Jatropha curcas L. Bioresour. Technol., 2011, 102 (2), 1194-1199.

[2] Demirba , A. Production of biodiesel from algae oils. Energy Sources A Recover. Util. Environ. Effects, 2009, 31 (2), 163-168.

[3] Demirbas, A. Importance of biodiesel as transportation fuel. Energy Policy, 2007, 35 (9), 4661-4670.

[4] Gui, M.; Lee, K.; Bhatia, S. Feasibility of edible oil vs. non-edible oil vs. waste edible oil as biodiesel feedstock. Energy, 2008, 33 (11), 1646-1653.

[5] Baroi, C.; Yanful, E. K.; Bergougnou, M. A. Biodiesel Production from $<$ em $>$ Jatropha curcas $</$ em $>$ Oil Using Potassium Carbonate as an Unsupported Catalyst. Int. J. Chem. Reactor Eng., 2009, 7 (7), 72.

[6] Augustus, G.; Jayabalan, M.; Seiler, G. Evaluation and bioinduction of energy components of Jatropha curcas. Biomass Bioenergy, 2002, 23 (3), 161-164.

[7] Aderibigbe, A.; Johnson, C.; Makkar, H.; Becker, K.; Foidl, N. Chemical composition and effect of heat on organic matter-and nitrogen-degradability and some antinutritional components of Jatropha meal. Anim. Feed Sci. Technol., 1997, 67 (2), 223-243.

[8] Juan, J. C.; Kartika, D. A.; Wu, T. Y.; Hin, T. Y. Y. Biodiesel production from jatropha oil by catalytic and non-catalytic approaches: An overview. Bioresour. Technol., 2011, 102 (2), 452460.

[9] Shah, S.; Sharma, S.; Gupta, M. Biodiesel preparation by lipasecatalyzed transesterification of Jatropha oil. Energy Fuels, 2004, 18 (1), 154-159.

[10] Muthu, H.; SathyaSelvabala, V.; Varathachary, T.; Kirupha Selvaraj, D.; Nandagopal, J.; Subramanian, S. Synthesis of biodiesel from Neem oil using sulfated zirconia via tranesterification. Braz. J. Chem. Eng., 2010, 27 (4), 601-608.

[11] (a) Muñoz-Valenzuela, S.; Ibarra-López, A. A.; Rubio-Silva, L. M.; Valdez-Dávila, H.; Borboa-Flores, J. Neem Tree Morphology and Oil Content. In: Issue In New Crops And New Uses; Janick, J.; Whipkey, A., Eds.; ASHS Press: Alexandria,VA, 2007, p.126.(b) Ragit, S. S.; Mohapatra, S. K.; Kundu, K.; Gill, P. Optimization of neem methyl ester from transesterification process and fuel characterization as a diesel substitute. Biomass Bioenergy, 2011, 35 (3), 1138-1144.

[12] Karmakar, A.; Karmakar, S.; Mukherjee, S. Biodiesel production from neem towards feedstock diversification: Indian perspective. Renewable Sustain. Energy Rev., 2011, 16 (1), 1050-1060.

[13] Martín, C.; Moure, A.; Martín, G.; Carrillo, E.; Domínguez, H.; Parajó, J. C. Fractional characterisation of jatropha, neem, moringa, trisperma, castor and candlenut seeds as potential feedstocks for biodiesel production in Cuba. Biomass Bioenergy, 2010, 34 (4), 533-538.

[14] (a) Ojolo, S. J.; Ogunsina, B. S.; Adelaja, A. O.; Ogbonnaya, M. Study of an Effective Technique for the Production of Biodiesel from Jatropha Oil. J. Emerg. Trends Eng. App. Sci., 2011, 2 (1), 79-86; (b) Belewu, M.; Adekola, F. A.; Adebayo, G. B.; Ameen, O. M.; Muhammed, N. O.; Olaniyan, A. M.; Adekola, O. F.; Musa, A. K. Physico-chemical characteristics of oil and biodiesel from Nigerian and Indian Jatropha curcas seeds. Int. J. Biol. Chem. Sci., 2010, 4 (2), 524-529.

[15] (a) Aransiola, E.; Betiku, E.; Ikhuomoregbe, D.; Ojumu, T. Production of biodiesel from crude neem oil feedstock and its emissions from internal combustion engines. Afr. J. Biotechnol., 2012, 11(22),6178-6186. (b) Aransiola, E. F. Kinetics of the conversion of refined Soybean Oil and Jatropha curcas Oil To Biodiesel. Phd Thesis, Obafemi Awolowo University: Ile - Ife, Nigeria, 2010.

[16] Berchmans, H. J.; Hirata, S. Biodiesel production from crude Jatropha curcas L. seed oil with a high content of free fatty acids. Bioresour. Technol., 2008, 99 (6), 1716-1721.

[17] Aransiola, E.; Betiku, E.; Layokun, S.; Solomon, B. Production of biodiesel by transesterification of refined soybean oil. Int. J. Biol. Chem. Sci., 2010, 4 (2), 391 - 399.

[18] Dubé, M. A.; Zheng, S.; McLean, D. D.; Kates, M. A comparison of attenuated total reflectance-FTIR spectroscopy and GPC for monitoring biodiesel production. J. Am. Oil Chem. Soc., 2004, 81 (6), 599-603.

[19] Darnoko, D.; Cheryan, M. Kinetics of palm oil transesterification in a batch reactor. J. Am. Oil Chem. Soc. 2000, 77 (12), 1263-1267.

[20] Bajpai, D.; Tyagi, V. Biodiesel: Source, production, composition, properties and its benefits. J. Oleo Sci., 2006, 55 (10), 487-502.

[21] (a) Banapurmath, N.; Tewari, P. Comparative performance studies of a 4-stroke CI engine operated on dual fuel mode with producer gas and Honge oil and its methyl ester (HOME) with and without carburetor. Renewable Energy, 2009, 34 (4), 1009-1015; (b) Rao, T. V.; Rao, G. P.; Reddy, K. H. C. Experimental investigation of pongamia, jatropha and neem methyl esters as biodiesel on CI engine. Jordan J. Mech. Ind.Eng., 2008, 2 (2), 117-122.

[22] Akbar, E.; Yaakob, Z.; Kamarudin, S. K.; Ismail, M.; Salimon, J. Characteristic and composition of Jatropha curcas oil seed from Malaysia and its potential as biodiesel feedstock feedstock. Eur. J. Sci. Res., 2009, 29 (3), 396-403. 